\title{
Length of cold stratification period affects germination in green alder (Alnus viridis (Chaix) DC. subsp. crispa (Aiton) Turrill) seed collected from northwestern Alberta
}

\author{
Jasmeen Kaur, Amanda L Schoonmaker, and Jean-Marie Sobze
}

ABSTRACT

Alnus viridis (Chaix) DC. subsp. crispa (Aiton) Turrill (Betulaceae), commonly known as green alder or mountain alder, is a boreal shrub used to revegetate disturbed lands because of its ability to persist and flourish in adverse conditions. Cold stratification, as a seed pretreatment, has been effective in breaking the embryo dormancy of green alder seed; however, the recommended duration of cold stratification varies from 0 to $60 \mathrm{~d}$. To determine the optimum time for seed collection and the impact of duration of cold stratification, seed was collected from 3 locations in 2013. One location was chosen for collection of seed over 3 consecutive mo. Seed was subjected to 4 cold stratification treatments at $+4{ }^{\circ} \mathrm{C}\left(39.2^{\circ} \mathrm{F}\right)$, and we included a non-treated control. Mean germination time was significantly lower with cold-stratified seed than with the non-stratified seed. Green alder seed showed more rapid and uniform germination when cold stratified for 2 wk or 6 wk as compared to $12 \mathrm{wk}$ of stratification or non-stratified. Germination rate of green alder seed was similar over a 3-mo collection period from late summer to fall.

Kaur J, Schoonmaker AL, Sobze J-M. 2016. Length of cold stratification period affects germination in green alder (Alnus viridis (Chaix) DC. subsp. crispa (Aiton) Turrill) seed collected from northwestern Alberta. Native Plants Journal 17(2):95-101.

\section{KEY WORDS}

boreal shrub, seed collection, revegetation, reclamation, synchronization index, seed stratification, Betulaceae

NOMENCLATURE

USDA NRCS (2015)

Photos by Jean-Marie Sobze

This open access article is distributed under the terms of the CC BY NC ND license (http:// creativecommons.org/licenses/byncnd/3.0) and is freely available online at: http://npj.uwpress.org. 
A lnus viridis (Chaix) DC. subsp. crispa (Aiton) Turrill (Betulaceae), commonly known as green alder or mountain alder, is a circumboreal species present from Alaska to Newfoundland and Greenland, south to New England and the Great Lakes States, and into the Pacific Northwest. It is found throughout northern Ontario but absent south of the Canadian Shield. Disjunct populations exist in Pennsylvania and North Carolina (Soper and Heimburger 1994). Green alder is well suited for revegetation of disturbed sites because of its ability to fix nitrogen (Dalton and Naylor 1975), ability to increase soil organic matter (Vogel and Gower 1998), rapid early growth, and high survival rates (Prégent and Camiré 1985). All species of alder enrich ecosystem nitrogen by means of a symbiotic relationship with the actinomycete Frankia spp. located in the root nodules. Approximately $45 \%$ of fixed nitrogen returns to the ecosystem through leaf fall, which also increases organic carbon (Schwencke and Carú 2001). Consequently, green alder is able to grow in nitrogen-poor soils and in harsh, stressful environments. Many researchers have described successful use of green alder for reclamation and revegetation of disturbed lands (Prégent and Camiré 1985; Vogel and Gower 1998; Bissonnette and others 2014).
Outplanting of nursery-produced green alder, commonly grown in $125 \mathrm{ml}(0.033 \mathrm{gal})$ containers, is a common mode of establishing this species on reclaimed sites. Optimizing seed germination is critical to successful nursery production. Treatments that have included light, moisture, temperature, manipulation, and surface sterilization have proved effective in breaking embryo dormancy and enhancing seed germination (Farmer and others 1985; Brunner and Brunner 1990). Cold stratification as a germination improvement method has been widely cited for green alder seed and offers twofold benefit: breaking seed dormancy and inducing uniform germination, which results in less variability in nursery stock. Even though cold stratification for green alder is recommended, the optimal length of stratification period has not been defined. Inconsistency is common in published reports regarding the time required to stratify green alder seed, varying from 0 to $60 \mathrm{~d}$ (Nichols 1934; Brunner and Brunner 1990; Wick and others 2008; Formaniuk 2013). The purpose of the present study is to identify the optimal stratification period for rapid and uniform germination of green alder seed. We also evaluate the impact of seed collection timing on germination of green alder seed.

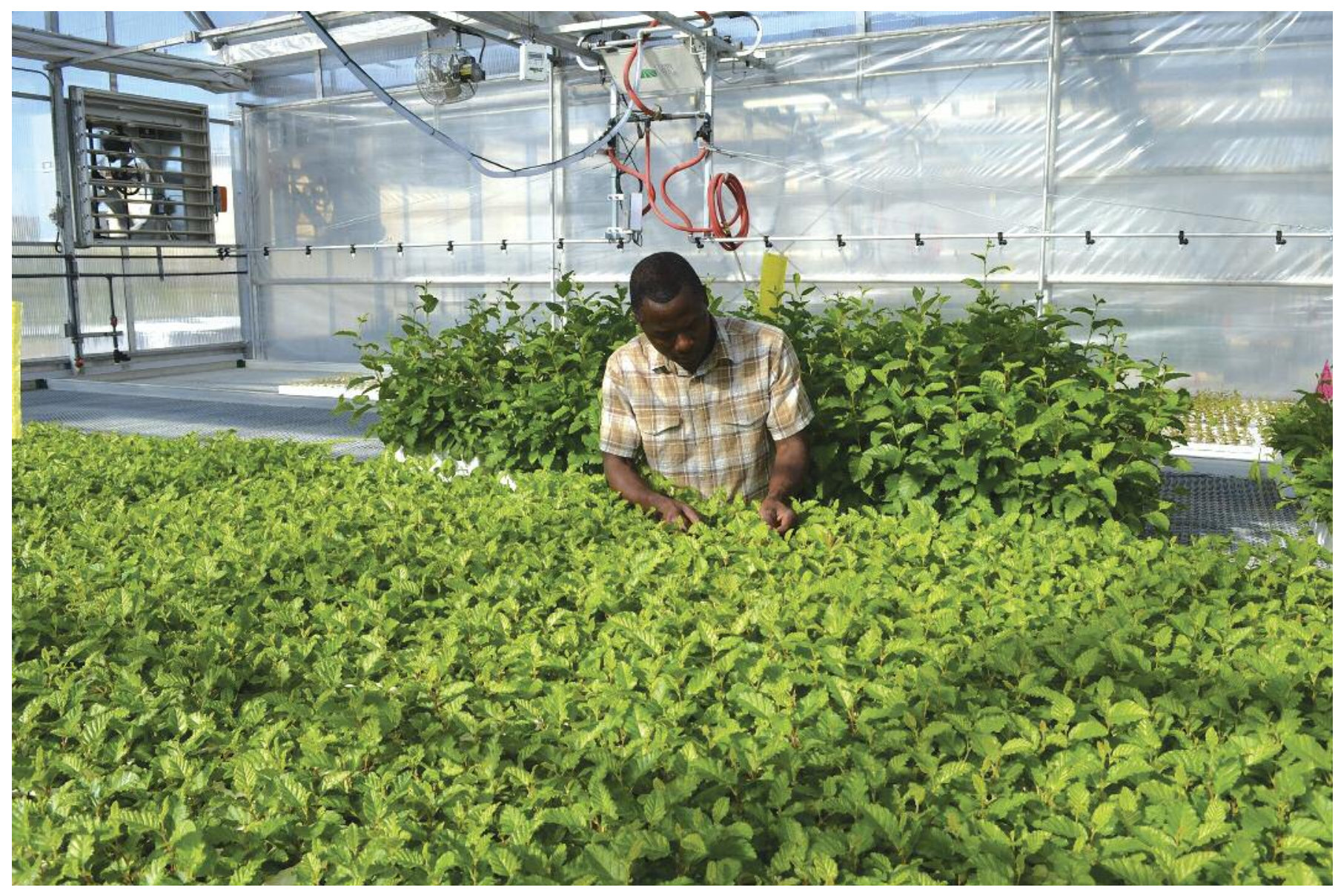

Nursery production of green alder seedlings. 


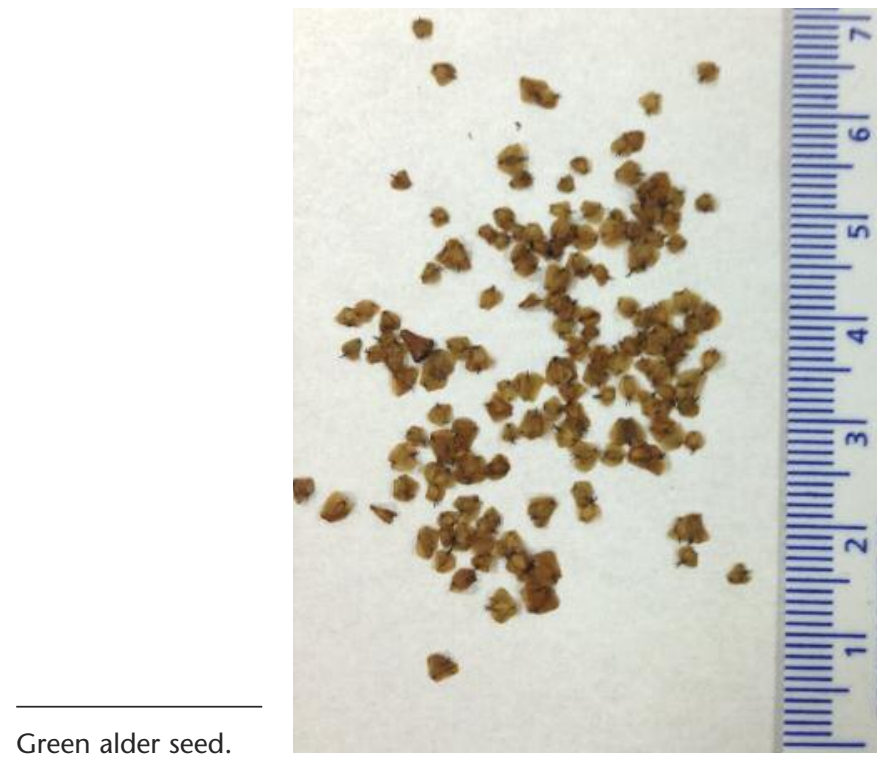

MATERIALS AND METHODS

Green alder seed was collected from 3 populations, designated SPL1, SPL2, and SPL3 (Figure 1) within the Peace River region in Alberta during August to October 2013. Population SPL1 was selected for seed collection in the subsequent months of
September and October to study the impact of collection timing on seed germination. Collected seed was extracted and stored in sealed containers. We placed seed in cold storage until it reached a desired moisture content of 3 to $10 \%$ (Gosling 2007; Hay and Probert 2013), at which point we transferred seed to a freezer for storage. Seed collection, extraction, and storage temperatures and dates, along with the storage moisture content of the green alder seedlots, are summarized in Table 1.

Cold stratification experiments were performed between March and July 2014. Treatments consisted of 3 stratification periods (2, 6, and $12 \mathrm{wk}$ ) and a non-stratified control (0 week). For each treatment, 4 replications of 50 seeds from each lot were germinated on moist, clean sand in Petri plates. All seed was pre-moistened and then stratified at $4{ }^{\circ} \mathrm{C}\left(39^{\circ} \mathrm{F}\right)$. Germination tests started on 27 February, 13 March, 16 April, and 28 May for the non-stratified, 2-wk, 6-wk, and 12-wk stratification treatments, respectively. Because the light requirement of green alder seed is overcome with stratification (Farmer and others 1985), we assumed that any differences in day length would not confound actual germination rates in our experiment. Seed in Petri plates was misted daily with deionized water using a spray bottle and incubated in the greenhouse under temperatures of 19 to $26^{\circ} \mathrm{C}\left(66\right.$ to $79^{\circ} \mathrm{F}$ ) (Figure 2) and 75 to $80 \%$ relative hu-

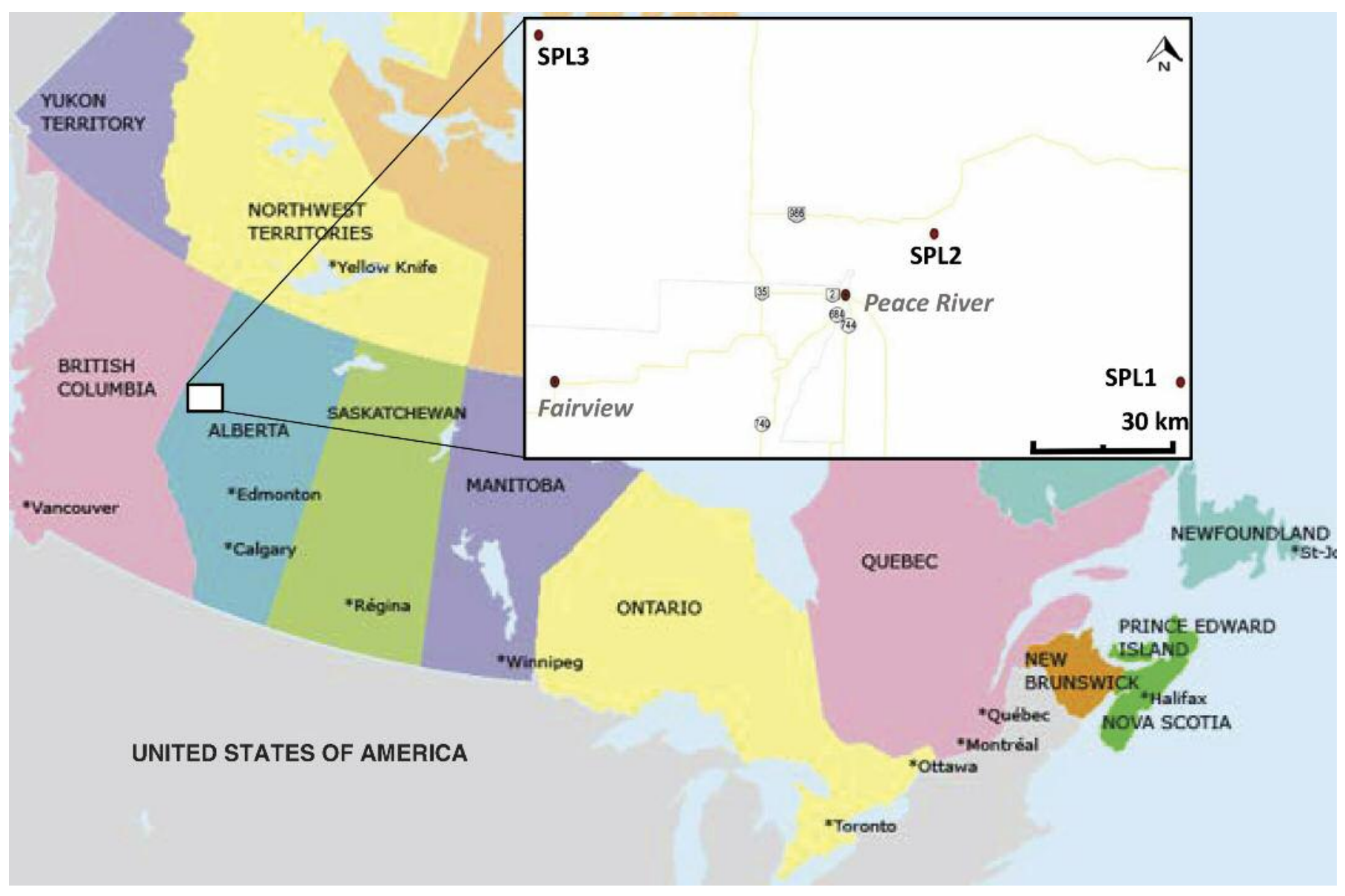

Figure 1. Map of Alberta showing collections sites for 3 seed populations, SPL1, SPL2, and SPL3, near the town of Peace River, Alberta. 
Dates and conditions for seed collection, extraction, and storage of green alder seedlots used in the stratification study.

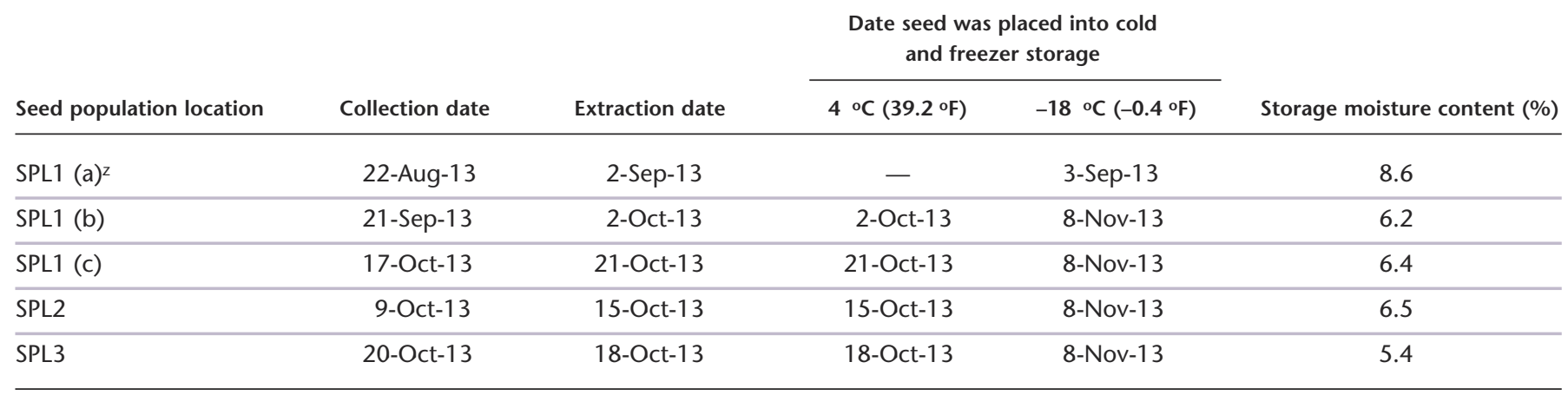

zSPL (a), (b), and (c) refer to seedlots collected from the SPL1 in August, September, and October 2013, respectively.

midity. Germinating seed was counted daily for $45 \mathrm{~d}$. Germinants were recorded once the radicle and both cotyledons were expanded; once germinated, we removed seed from the Petri plates.

Statistical analysis was performed with $\mathrm{R}$ ( $\mathrm{R}$ Core Team 2015). A Weibull function was chosen for comparing cumulative germination across treatments because its parameters are biologically interpretable and reflect maximum germination, germination rate, lag in the onset of germination, and accurately reflect the shape of a cumulative distribution (Brown and
Mayer 1988). Using the "drc" package in $\mathrm{R}$, the following Weibull function was fitted to cumulative germination percentage within each of treatments and collection population (Ritz and Strebig 2005):

$$
Y=M\left\{1-e^{-[k(t-z)]^{c}}\right\}
$$

where $Y=$ germination percentage at time $t$ (days), $M=$ final germination (at 45th day), $z=$ lag time until initiation of germination $(d), k=$ spacing function, and $c=$ curve shape parameter. We calculated the time to reach 50\% (T50) and 90\% (T90)

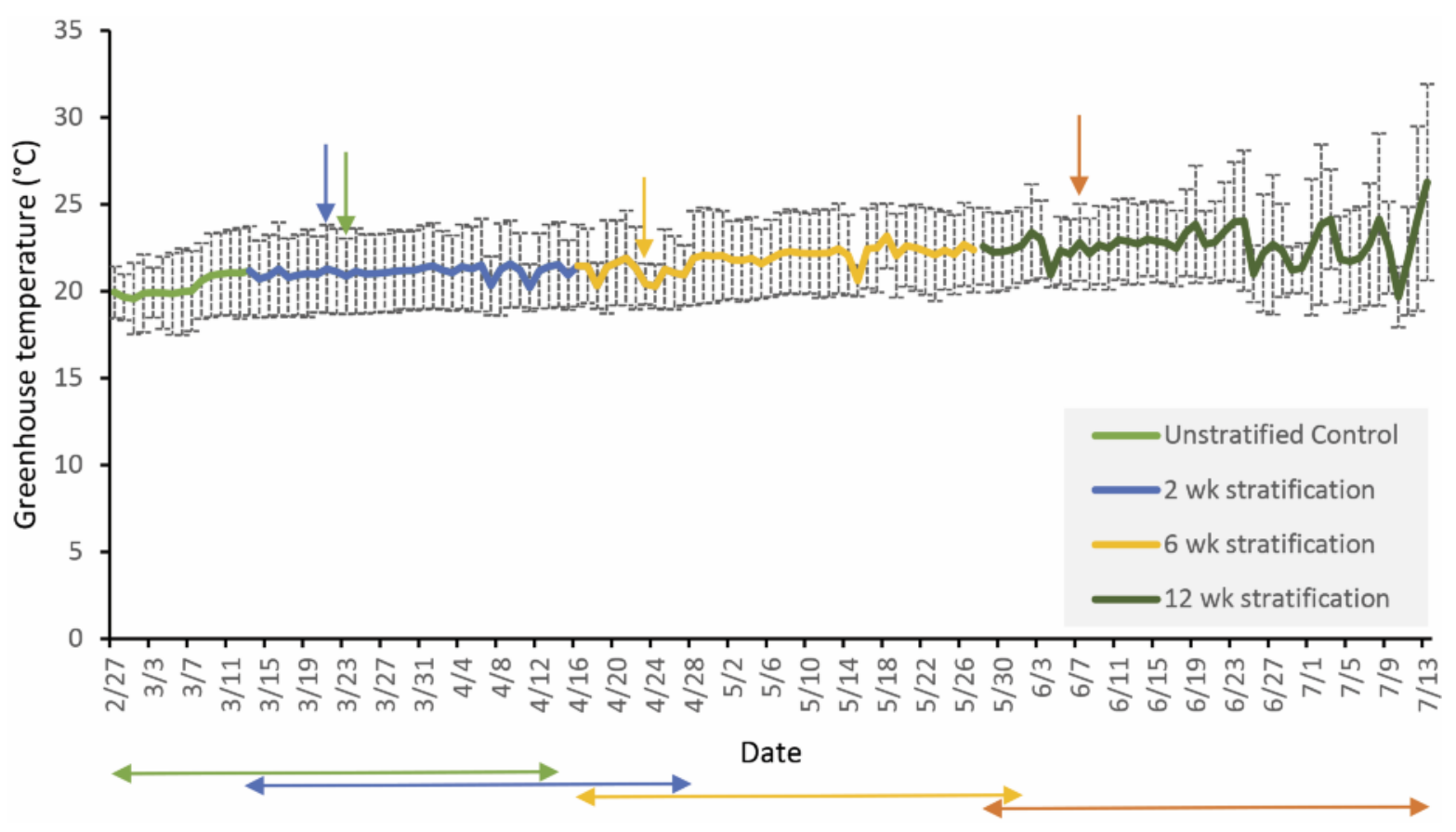

Figure 2. Variation in greenhouse daily temperature over the study period overlaid with germination results for stratification treatments.

Notes: Error bars represent one standard deviation of the mean for temperature $(n=8)$. Double-headed (horizontal) arrows below the graph represent the germination duration ( $45 \mathrm{~d}$ ) of each treatment, and single-headed (vertical) arrows above 
germination of seed for each population from the parameter estimates of the Weibull function.

Mean germination time $(\bar{t})$ was calculated as

$$
\frac{\sum_{i=1}^{k} n_{i} t_{i}}{\sum_{i=1}^{k} n_{i}}
$$

where $t_{i}$ is the time from the start of the experiment to the $i^{\text {th }}$ observation $(d), n_{i}$ is the number of seeds germinated on the $i^{\text {th }}$ day, and $k$ is the final day of experiment (45th d). Synchronization index $(\bar{E})$ measures asynchrony associated with the distribution of the relative frequency of germination and is expressed by

$$
\bar{E}=-\sum_{i=1}^{k} f_{i}^{*} \log _{2} f_{i}
$$

where $k$ is the last day of observation and $f_{i}$ is the relative frequency of germination given by $f_{i}=\frac{n_{i}}{\sum_{i=1}^{k} n_{i}}$. Lower values
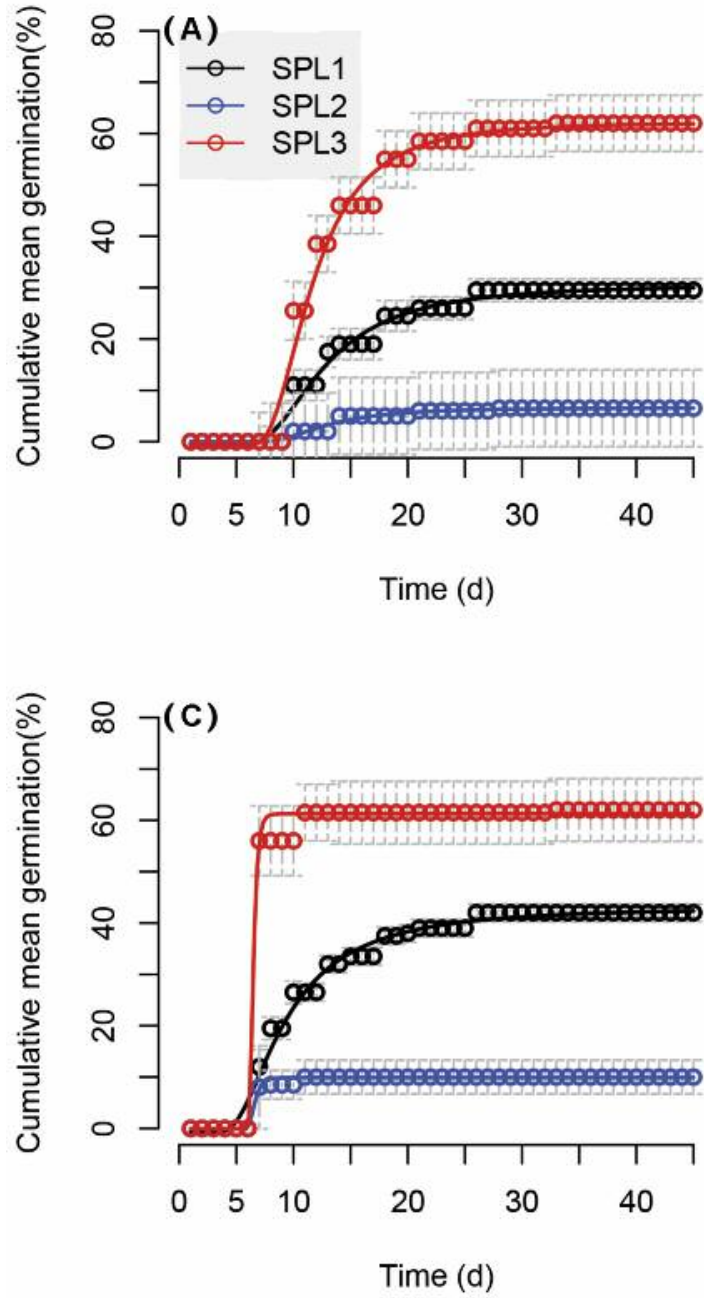

of $\bar{E}$ indicate more synchronized germination. This parameter is important to consider for practical reasons as it is desirable for seed to germinate with as little spread in time as possible.

Percent average germination of green alder seed across 3 cold stratification treatments and the non-stratified control was compared using one-way analysis of variance (ANOVA). Mixed-model ANOVAs were performed to compare T50, T90, $\bar{t}$, and $\bar{E}$ using "lme4" package in R (Bates and others 2015) with seed population location as a random effect. Mean $(P \leq 0.05)$ differences among treatments for T50,T90, $\bar{t}$ and $\bar{E}$ were compared with a Tukey test.

\section{RESULTS AND DISCUSSION}

\section{Length of Cold-Stratification Period}

The number of days required for maximum germination varied among treatments (Figure 3). The total germination percentage of green alder seed, however, did not vary significantly
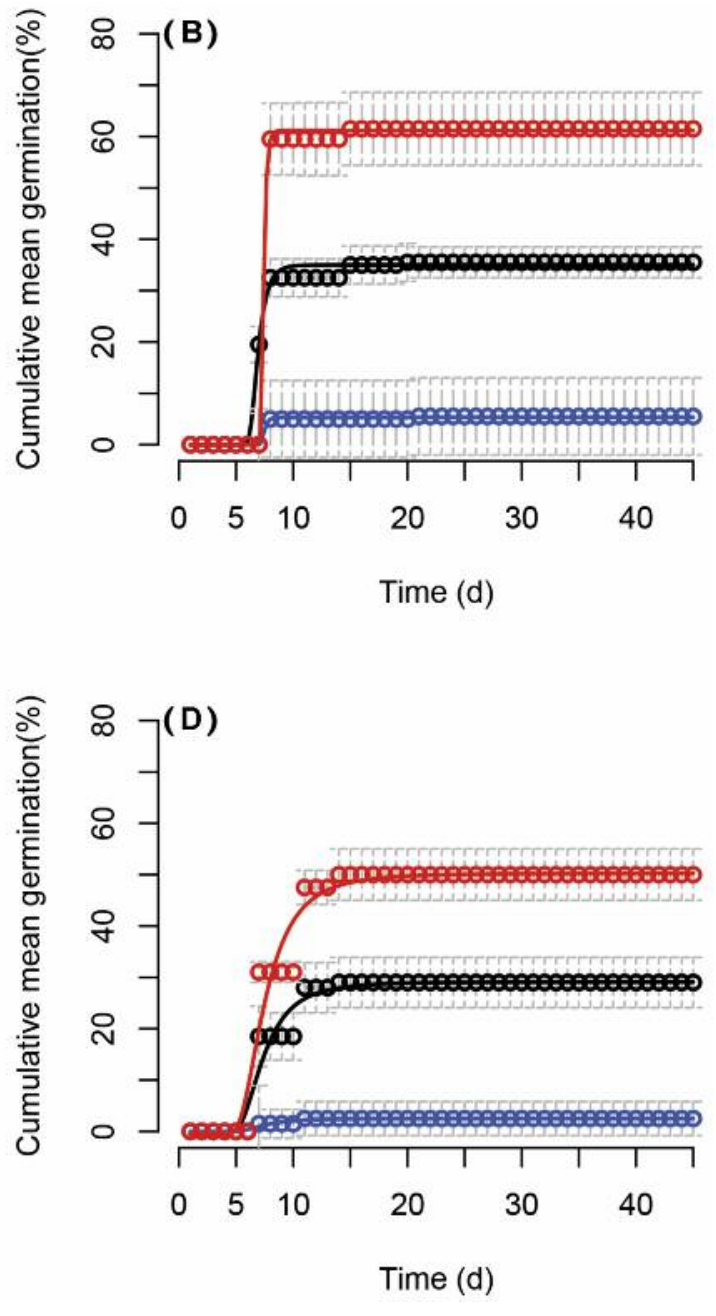

Figure 3. Mean cumulative germination of green alder seed in response to different cold stratification treatments: non-stratified control (A); 2-wk stratification (B); 6-wk stratification (C); 12-wk stratification (D), over a period of $45 \mathrm{~d}$. Notes: Circles represent the treatment means and error bars represent one standard deviation of the mean $(n=4)$. Curves represent the Weibull function-fit of the means. 
across 3 cold stratification regimes nor in comparison with the non-stratified control for any of the 3 seed collection populations $(P \leq 0.05$; Figure 4$)$.

Non-stratified seed took an average of $22.2 \mathrm{~d}$ to achieve $90 \%$ germination, whereas the same fraction of seed that was coldstratified for $2 \mathrm{wk}, 6 \mathrm{wk}$, and $12 \mathrm{wk}$ germinated in 7.9, 8.0, and $11.5 \mathrm{~d}$, respectively (Table 2 ). Non-stratified seed and seed stratified for 12 wk took 9.6 and $4 \mathrm{~d}$, respectively, to advance from 50 to $90 \%$ germination, whereas the 2 -wk and 6 -wk treatments took only 0.6 and $1.3 \mathrm{~d}$. Hence, cold stratification for 2 wk and 6 wk will likely lead to higher germination uniformity in the nursery. This uniformity is also reflected in a significant reduction in synchronization index between non-stratified and stratified seed (Table 2). Improving the uniformity of germina-

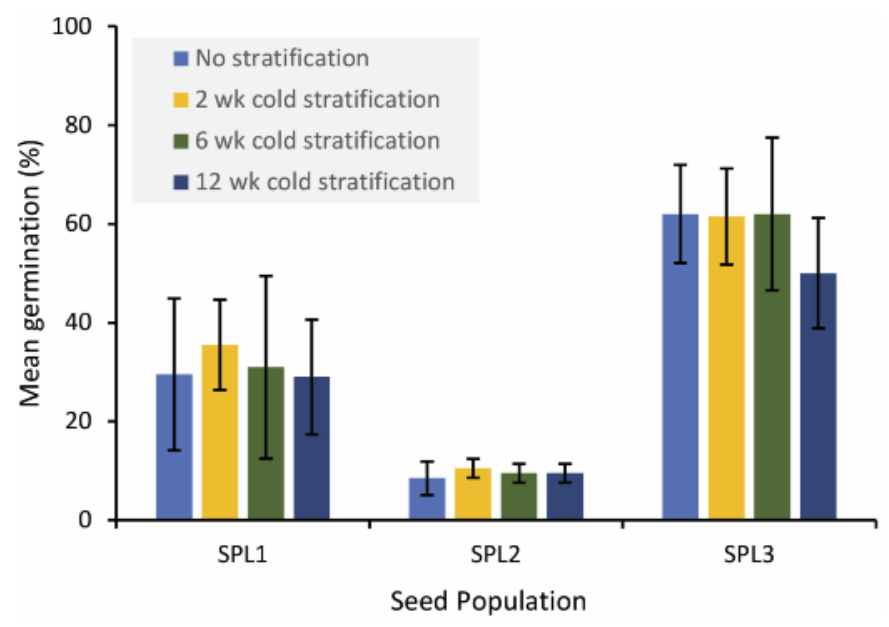

Figure 4. Mean germination of green alder seed across 3 seed population locations and 4 cold-stratification treatments (including control) after $45 \mathrm{~d}$.

Notes: Error bars represent one standard deviation of the mean $(n=4)$.

TABLE 2

Effect of cold stratification treatments on time to reach $50 \%$ germination (T50), time to reach 90\% germination (T90), mean germination time $(\bar{t})$, and synchronization index $(\bar{E})$ of green alder seed averaged across 3 seed populations.

\begin{tabular}{lcccc} 
Parameter & $\begin{array}{c}\text { Non-stratified } \\
\text { control }\end{array}$ & $\begin{array}{c}\text { 2-wk } \\
\text { stratification }\end{array}$ & $\begin{array}{c}\text { 6-wk } \\
\text { stratification }\end{array}$ & $\begin{array}{c}\text { 12-wk } \\
\text { stratification }\end{array}$ \\
\hline T50 & $12.6 \mathrm{a}(0.6)$ & $7.3 \mathrm{~b}(0.2)$ & $6.7 \mathrm{~b}(0.2)$ & $7.5 \mathrm{~b}(0.1)$ \\
\hline T90 & $22.2 \mathrm{a}(2.2)$ & $7.9 \mathrm{~b}(0.1)$ & $8.0 \mathrm{~b}(1.1)$ & $11.5 \mathrm{c}(0.2)$ \\
\hline $\bar{t}$ & $14.5 \mathrm{a}(0.6)$ & $8.5 \mathrm{~b}(0.5)$ & $7.8 \mathrm{~b}(0.2)$ & $8.6 \mathrm{~b}(0.0)$ \\
$\overline{\bar{E}}$ & $2.1 \mathrm{a}(0.3)$ & $0.7 \mathrm{~b}(0.5)$ & $0.7 \mathrm{~b}(0.2)$ & $1.1 \mathrm{~b}(0.1)$ \\
\hline
\end{tabular}

Notes: Standard deviation of the mean is in parentheses $(n=4)$. Means followed by same letters are not significantly different at $P \leq 0.05$ (Tukey test). tion is more likely to result in a less variable size distribution of nursery stock seedlings and is a desirable outcome for growers.

Only $50 \%$ of seeds germinated in the 12 -wk treatment, whereas a maximum of $61.5 \%$ and $62 \%$ of seeds geminated in the 2-wk and 6-wk treatments, respectively. These percentages are twice that of green alder seed that germinated under optimal light conditions as reported by other researchers. Smreciu and others (2014) reported 1 to 20\% germination of green alder seed stored at ambient conditions for up to $1 \mathrm{y}$ and stratified for $30 \mathrm{~d}$. Harrington and others (2008) obtained $28 \%$ germination at day/night temperature of $30 / 20{ }^{\circ} \mathrm{C}\left(86 / 68{ }^{\circ} \mathrm{F}\right)$ for 1 -y-old seed after 60 -d cold stratification. Wick and others (2008) recommended a 24 -h water soak followed by a 60 -d cold, moist stratification at $3{ }^{\circ} \mathrm{C}\left(37.4^{\circ} \mathrm{F}\right)$. Because the seed in the present study originated from different locations but were collected, extracted, stored, stratified, and germinated in similar conditions as for past experiments, seed germination variability among the seed locations may have been attributable to a number of other factors including seed quality and maturity, weather conditions during seed maturation, and genetics (Atrip and O'Reilly 2007). In addition, Ann Smreciu (personal communication 2015) has observed and suggested that green alder seed will lose substantial viability without prompt extraction and cold storage.

\section{Time of Seed Collection}

Average germination did not differ significantly among the seed collected at different times from population SPL1 during the months of August, September, and October 2013 ( $P \leq 0.05$; Figure 5). The overall trend, however, showed higher average germination in August compared to September and October for all treatments. Additional studies are required to confirm the consistency and relevance of this trend.

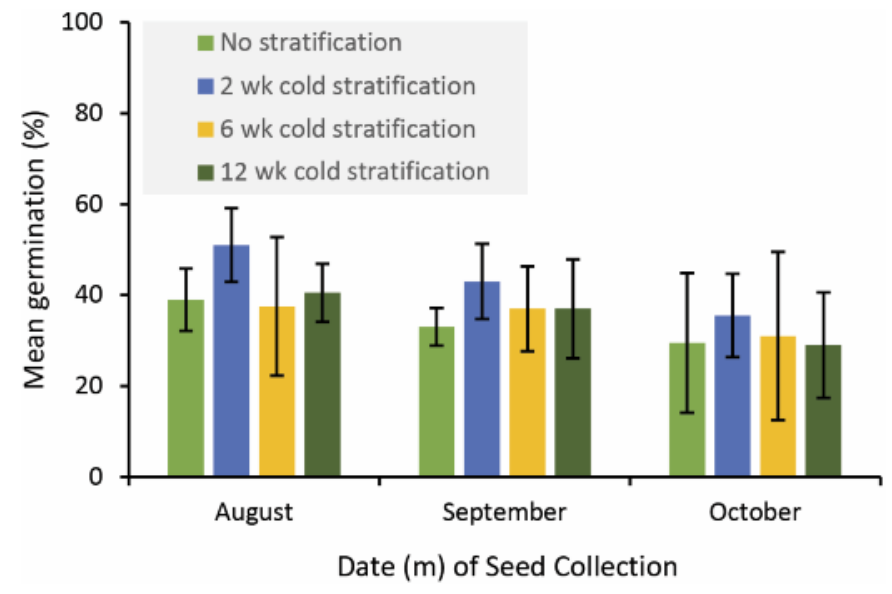

Figure 5. Mean germination of green alder seed collected in 3 consecutive mo in summer and fall 2013 and subjected to 4 cold-stratification treatments.

Notes: Error bars represent one standard deviation of the mean $(n=4)$. 


\section{CONCLUSION}

Results of the present study indicate that cold stratification in green alder seed significantly reduced time to achieve $50 \%$ and $90 \%$ germination, mean germination time, and synchronization index. On average, seed cold stratified for $2 \mathrm{wk}$ or $6 \mathrm{wk}$ tended to display higher germination and lower synchronization index as compared with those cold stratified for $12 \mathrm{wk}$. We also observed that seed collection immediately after seed maturity (August) did not show significantly different germination after cold stratification from those collected in September and October.

\section{ACKNOWLEDGMENTS}

We thank the Natural Sciences and Engineering Research Council of Canada (NSERC), the Canada Foundation for Innovation (CFI), PennWest Exploration Limited, and Shell Canada Limited for funding the study. We also thank Adele Boschma, Sally Barkwell, and Ryan O'Neil for their work in the laboratory.

\section{REFERENCES}

Atrip ND, O'Reilly C. 2007. Germination response of alder and birch seeds to applied gibberellic acid and priming treatments in combination with chilling. Annals of Forest Science 64:385-394.

Bates D, Maechler M, Bolker B, Walker S. 2015. Fitting linear mixedeffects models using Ime4. 51 p. The R Project, CRAN Repository.

Bissonnette C, Fahlman B, Peru KM, Khasa DP, Greer CW, Headley JV, Roy S. 2014. Symbiosis with Frankia sp. benefits the establishment of Alnus viridis ssp. crispa and Alnus incana ssp. rugosa in tailings sand from the Canadian oil sands industry. Ecological Engineering 68:167-175.

Brown RF, Mayer DG. 1988. Representing cumulative germination. 2. The use of the Weibull function and other empirically derived curves. Annals of Botany 61:127-138.

Brunner F, Brunner I. 1990. A new method to produce numerous uncontaminated alder seedlings. European Journal of Forest Pathology 20:430-435.

Dalton DA, Naylor AW. 1975. Studies on nitrogen fixation by Alnus crispa. American Journal of Botany 62:76-80.

Farmer RE Jr, Maley ML, Stoehr MU, Schnekenburger F. 1985. Reproductive characteristics of green alder in northwestern Ontario. Canadian Journal of Botany 63:2243-2247.

Formaniuk S. 2013. It's all in the timing. Canadian Reclamation 13:2631.

Gosling P. 2007. Raising trees and shrubs from seed, Forestry Commission practice guide. Edinburgh: Forestry Commission.

Harrington C, Brodie LC, DeBell DS, Schopmeyer CS. 2008. Alnus P. Mill.: alder. In: Bonner FT, Karrfalt RP, editors. The woody plant seed manual. Agriculture Handbook No. 727. Washington (DC): USDA Forest Service. p 232-242.
Hay FR, Probert RJ. 2013. Advances in seed conservation of wild plant species: a review of recent research. Conservation Physiology 1:111.

Nichols GE. 1934. The influence of exposure to winter temperatures upon seed germination in various native American plants. Ecology 15:364-373.

Prégent G, Camiré C. 1985. Biomass production by alders on four abandoned agricultural soils in Québec. Plant Soil 87:185-193.

R Core Team. 2015. R: A language and environment for statistical computing. Vienna, Austria: R Foundation for Statistical Computing.

Ritz C, Strebig JC. 2005. Bioassay analysis using R. Journal of Statistical Software 12(5):1-22.

Schwencke J, Carú M. 2001. Advances in actinorhizal symbiosis: host plant-Frankia interactions, biology, and applications in arid land reclamation. A review. Arid Land Research and Management 15:285-327.

Smreciu A. 2015. Personal communication. Wild Rose Consulting Inc, Edmonton, Alberta. Director.

Smreciu A, Gould K, Wood S. 2014. Establishment of native boreal plant species on reclaimed oil sands mining disturbances: Final report. Canadian Oil Sands Research and Development (CONRAD). $51 \mathrm{p}+$ appendices.

Soper JH, Heimburger ML. 1994. Shrubs of Ontario. Royal Ontario Museum. p 95-96.

[USDA NRCS] USDA Natural Resources Conservation Service. 2015. The PLANTS database. URL: http://plants.usda.gov (accessed 16 Dec 2015). Greensboro (NC): National Plant Data Team.

Vogel JG, Gower ST. 1998. Carbon and nitrogen dynamics of boreal jack pine stands with and without a green alder understory. Ecosystems 1:386-400.

Wick D, Luna T, Hosokawa J. 2008. Propagation protocol for production of container Alnus viridis (Chaix.) DC. sinuata (Regel) Love \& Love plants (172 ml containers). USDI NPS, Glacier National Park, West Glacier, Montana. Native Plant Network. URL: http:// npn.rngr.net/npn/.

\section{AUTHOR INFORMATION}

Jasmeen Kaur

Research Officer

jasmeenk@nait.ca

Amanda L Schoonmaker

NSERC Industrial Research Chair

aschoonmaker@nait.ca

Jean-Marie Sobze

Plant and Seed Research Coordinator

jeanmars@nait.ca

NAIT Boreal Research Institute

810299 Avenue

Peace River, AB T8S 1R2 


\section{Advertise in Native Plants Journal}

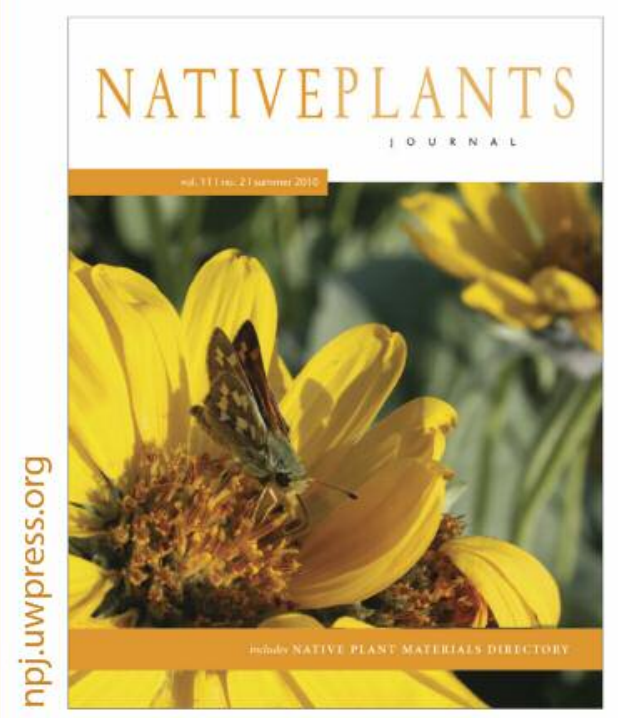

Edited by Stephen Love, published 3/year

For nearly 50 years, UW Press has published quality scholarly and professional journals. We offer a variety of advertising options to meet your needs, including online ads, to ensure your promotions are seen by a wide audience of professionals.

We offer:

- Great rates and flexible pricing models.

- Direct exposure of your program, conference, publications, products, or services to the Native Plants Journal reader including scientists, academics, field personnel, nursery managers, and others interested in all aspects of growing and planting native plants, including the US Department of the Interior, Bureau of Land Management, and US Army Corps of Engineers.

\section{Contact Chloe Lauer today! (608) 263-0534 or chloe.lauer@wisc.edu} 1930 Monroe Street, $3^{\text {rd }}$ F1., Madison, WI 53711-2059 USA | journals@uwpress.wisc.edu Phone: (608) 263-0668 • Fax: (608) 263-1173 or (US only) (800) 258-3632 | http://uwpress.wisc.edu/journals

\section{NATIVEPI A NTS Annual Native Plant Materials Directory}

Each year, the summer issue of Native Plants Journal includes a directory of native plant growers and suppliers.

\section{Basic Directory Listing (Free)}

Every company listed in the National Nursery and Seed Directory at www.rngr.net/resources/directory is included at a Basic Listing level at no charge.

\section{Enhanced Directory Listing ( $\$ 40$ for subscribers, $\$ \mathbf{6 5}$ for nonsubscribers)}

Selecting the Enhanced Listing level allows your company to stand out with a highlighted listing that features a 125-word description and your company name in bolder font.

To request an Enhanced Listing, add your company to the National Nursery and Seed Directory, or update a previous listing, call (608) 263-0534 or email journal.ads@uwpress.wisc.edu. 